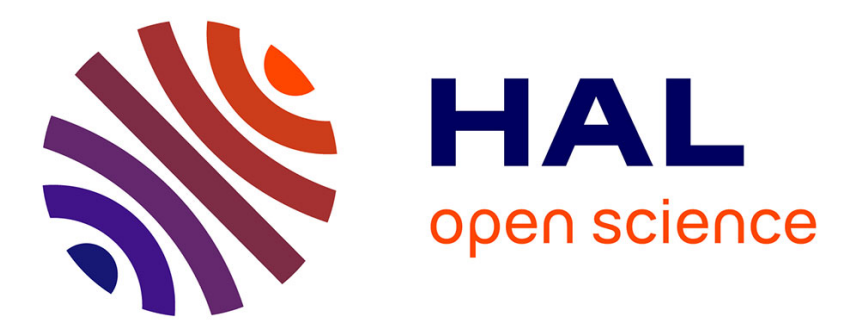

\title{
Evaluation of thermal comfort in galatsi arena of the olympics "Athens 2004" using a CFD model
}

\author{
Anastasios I. Stamou, Ioannis Katsiris, Alois Schaelin
}

\section{To cite this version:}

Anastasios I. Stamou, Ioannis Katsiris, Alois Schaelin. Evaluation of thermal comfort in galatsi arena of the olympics "Athens 2004" using a CFD model. Applied Thermal Engineering, 2008, 28 (10), pp.1206. 10.1016/j.applthermaleng.2007.07.020 . hal-00498959

\section{HAL Id: hal-00498959 \\ https://hal.science/hal-00498959}

Submitted on 9 Jul 2010

HAL is a multi-disciplinary open access archive for the deposit and dissemination of scientific research documents, whether they are published or not. The documents may come from teaching and research institutions in France or abroad, or from public or private research centers.
L'archive ouverte pluridisciplinaire HAL, est destinée au dépôt et à la diffusion de documents scientifiques de niveau recherche, publiés ou non, émanant des établissements d'enseignement et de recherche français ou étrangers, des laboratoires publics ou privés. 


\section{Accepted Manuscript}

Evaluation of thermal comfort in galatsi arena of the olympics "Athens 2004" using a CFD model

Anastasios I. Stamou, Ioannis Katsiris, Alois Schaelin

PII:

S1359-4311(07)00264-5

DOI:

10.1016/j.applthermaleng.2007.07.020

Reference:

ATE 2242

To appear in:

Applied Thermal Engineering

\section{APPLIED}

THERMAL

ENGINEERING

$\begin{array}{ll}\text { Received Date: } & \text { 24 May } 2007 \\ \text { Revised Date: } & \text { 5 June } 2007\end{array}$

Accepted Date: $\quad 31$ July 2007

Please cite this article as: A.I. Stamou, I. Katsiris, A. Schaelin, Evaluation of thermal comfort in galatsi arena of the olympics “Athens 2004" using a CFD model, Applied Thermal Engineering (2007), doi: 10.1016/j.applthermaleng. 2007.07.020

This is a PDF file of an unedited manuscript that has been accepted for publication. As a service to our customers we are providing this early version of the manuscript. The manuscript will undergo copyediting, typesetting, and review of the resulting proof before it is published in its final form. Please note that during the production process errors may be discovered which could affect the content, and all legal disclaimers that apply to the journal pertain. 


\title{
EVALUATION OF THERMAL COMFORT IN GALATSI ARENA OF THE OLYMPICS “ATHENS 2004” USING A CFD MODEL
}

\author{
Anastasios I. Stamou, ${ }^{\text {a,* }}$ Ioannis Katsiris ${ }^{\text {a }}$, Alois Schaelin ${ }^{\text {b }}$ \\ ${ }^{a}$ School of Civil Engineering, National Technical University of Athens, Iroon \\ Polytechniou 5, 15780 Athens, Greece \\ ${ }^{b}$ Air flow Consulting, Weinbergstrasse 72, CH-8006 Zürich, Switzerland
}

\begin{abstract}
A Computational Fluid Dynamics (CFD) model was used to evaluate the thermal comfort conditions in the indoor stadium of the Galatsi Arena, which hosted the sports of rhythmic gymnastics and table tennis during the Olympic Games "Athens 2004". The CFD code CFX was applied to calculate the 3-D airflow and temperature fields in the Arena for various values of temperatures $\left(T_{\text {in }}\right)$ of conditioned inlet air. Calculated mean velocities and temperatures were used to determine the thermal comfort indices PMV (Predicted Mean Vote) and PPD (Predicted Percentage of Dissatisfied) and to evaluate the thermal conditions in the various regions of the Arena. Calculated PMV and PPD values showed that thermal conditions in the Galatsi Arena were very satisfactory for $\mathrm{T}_{\text {in }}=16^{\circ} \mathrm{C}$; only a small percentage (less than $7 \%$ ) of the spectators was expected to be slightly uncomfortable.
\end{abstract}

Corresponding author. Tel.: +30 210772 2809; fax: +30 2107722814 .

E-mail addresses: stamou@ central.ntua.gr, ykats@mail.ntua.gr, www.afc.ch. 
Key words. Computational Fluid Dynamics (CFD); indoor stadiums; mathematical models; thermal comfort

\section{Introduction}

In the last two decades Computational Fluid Dynamics (CFD) models have been increasingly used for the calculation of airflow velocities and temperatures in indoor environments for the evaluation of comfort conditions, smoke conditions and air quality. A significant number or scientific papers exists dealing with the application of CFD models in various indoor environments, such as apartments [1], offices [2,3], museums [4], lecture theatres [5], classrooms [6], clinics [7], industrial premises [8] and car parks [9]. Moreover, CFD models have been combined with other tools or methods for the design of indoor spaces. For example; Desta et al [10] combined a CFD model with a low order Data Based Mechanistic (DBM) model to predict air temperatures in a full scale, adiabatic walled ventilated test chamber. The CFD model supplied data and the DBM model performed model order reduction; in this way the two modeling approaches supplemented each other symbiotically to eliminate their disadvantages. Zhai and Chen [11] analyzed the potential building and environmental characteristics (such as environmental conditions, HVAC systems, building occupying and operating conditions, envelope properties and building sizes) that may influence the necessity and effectiveness of applying Energy Simulation-CFD coupling simulation. They conducted a sensitivity analysis of the coupling simulation in a representative office building in Boston and provided general suggestions on appropriate development and usage of the coupling simulation. Kim et al [12] presented a two-step optimal design investigation 
method using Genetic Algorithms for CFD indoor thermal environments and applied the optimal design in an office space.

In spite of the extensive application of CFD models in various indoor environments, there are only a few studies in indoor stadia. In 2001 a CFD model was applied for the Yoyogi National Stadium in Tokyo [13]. The Stadium was constructed for the Olympics of 1964. Since then, it has continued to be used for the performance of swimming competitions or concerts; the CFD model was used to evaluate indoor conditions for both modes of stadium operation. Very recently, a CFD study was performed in the Olympic ice hockey stadium in Turin to evaluate fire hazards; smoke conditions were reviewed in the stadium for various scenarios and uses [14].

The present work demonstrates the application of a CFD model to calculate air flow velocities and temperatures in the Galatsi Arena, shown in Figure 1; the Arena hosted the sports of rhythmic gymnastics and table tennis during the Olympics of 2004. The calculated velocities and temperatures were used to determine the main thermal comfort indices Predicted Mean Vote (PMV) and Predicted Percentage of Dissatisfied (PPD) [15]; these were subsequently used for the evaluation of the thermal conditions in the Arena.

\section{The mathematical model}

\subsection{The CFD code}

There are three main types of CFD methods: (1) Direct Numerical Simulation (DNS), (2) Large Eddy Simulation (LES) and (3) Reynolds Averaged Navier-Stokes (RANS). A short presentation of these methods can be found in Stamou and Katsiris [3]. These methods are employed in various efficient computer codes, which are most frequently 
used for indoor CFD calculations, such as PHOENICS [16], FLUENT [17] and CFX [18]. In the present work, the latest version of the computer code CFX [18] was used.

The CFX code calculates the 3-D flow field and heat transfer using the continuity, momentum and energy equations, which are written as follows:

$$
\begin{aligned}
& \frac{\partial \rho U_{j}}{\partial x_{j}}=0 \\
& \frac{\partial \rho U_{i}}{\partial t}+\frac{\partial \rho U_{j} U_{i}}{\partial x_{j}}=-\frac{\partial P}{\partial x_{i}}+\frac{\partial}{\partial x_{j}}\left(\mu \frac{\partial U_{i}}{\partial x_{j}}+R T S\right)+g_{i} \rho \\
& \frac{\partial T}{\partial t}+\frac{\partial \rho U_{j} T}{\partial x_{j}}=\frac{\partial}{\partial x_{j}}\left(\mu \frac{\partial T}{\partial x_{j}}+T T S\right)
\end{aligned}
$$

where $\mathrm{t}$ is the time, $\mathrm{x}_{\mathrm{i}}$ is the Cartesian coordinate in the $\mathrm{i}$-direction, $\mathrm{U}_{\mathrm{i}}$ is the flow velocity in the $\mathrm{i}$ - direction, $\rho$ is the density of water, $\mathrm{T}$ is the temperature, $\mathrm{P}$ is the pressure, $\mu$ is the molecular viscosity of the water and $\mathrm{g}_{\mathrm{i}}$ is the acceleration of gravity.

For the calculation of the Reynolds (turbulent) stresses (RTS), the assumption of the isotropic turbulence is applied combined with the Bussinesq approximation, i.e.

$$
R T S=\mu_{t}\left(\frac{\partial U_{i}}{\partial x_{j}}+\frac{\partial U_{j}}{\partial x_{i}}\right)-\frac{2}{3} \rho k \delta_{i j}
$$

where $\mu_{\mathrm{t}}$ is the eddy viscosity, $\delta_{\mathrm{ij}}$ is the Kronecker delta $\left(\delta_{\mathrm{ij}}=1\right.$ for $\mathrm{i}=\mathrm{j}$ and $\delta_{\mathrm{ij}}=0$ for $\mathrm{i}$ 开 $)$ and $\mathrm{k}$ is the average turbulent kinetic energy per unit mass, given by

$$
k=\frac{1}{2}\left(\overline{u_{1}^{2}}+\overline{u_{2}^{2}}+\overline{u_{3}^{2}}\right)
$$

Similarly, the Turbulent Thermal Stresses (TTS) are calculated by the following equation

$$
T T S=\frac{\mu_{t}}{\sigma_{\mathrm{T}}} \frac{\partial \mathrm{T}}{\partial x_{j}}
$$

where $\sigma_{\mathrm{T}}$ is the turbulent Schmidt number for T. 


\subsection{The turbulence model}

In the present work, turbulence is modeled with the Shear Stress Transport (SST) k- $\omega$ based model [19]. This model combines the standard k- $\varepsilon$ model [20] and the k- $\omega$ model [21]; virtually, it is a transformation of the $\mathrm{k}-\varepsilon$ to a $\mathrm{k}-\omega$ formulation and a subsequent addition of certain equations.

The standard k- $\varepsilon$ turbulence model [20] relates the eddy viscosity to $\mathrm{k}$ and the rate of its dissipation $(\varepsilon)$ via the following equation.

$$
\mu_{t}=\rho_{c_{\mu}} \frac{k^{2}}{\varepsilon}
$$

where $c_{\mu}$ is an empirical constant and $\varepsilon$ is given by the following equation

$$
\varepsilon=\frac{\mu}{\rho} \overline{\frac{\partial u_{i}}{\partial x_{j}} \frac{\partial u_{i}}{\partial x_{j}}}
$$

The distributions of $\mathrm{k}$ and $\varepsilon$ are calculated from the following semi-empirical modeled transport equations

$$
\begin{aligned}
& \frac{\partial \rho k}{\partial t}+\frac{\partial \rho U_{j} k}{\partial x_{j}}=\frac{\partial}{\partial x_{j}}\left(\frac{\mu_{t}}{\sigma_{k}} \frac{\partial k}{\partial x_{j}}\right)+G-\rho \varepsilon \\
& \frac{\partial \rho \varepsilon}{\partial t}+\frac{\partial \rho U_{j} \varepsilon}{\partial x_{j}}=\frac{\partial}{\partial x_{j}}\left(\frac{\mu_{t}}{\sigma_{\varepsilon}} \frac{\partial \varepsilon}{\partial x_{j}}\right)+c_{1} \frac{\varepsilon}{k} G-\rho c_{2} \frac{\varepsilon^{2}}{k}
\end{aligned}
$$

where $\mathrm{G}$ is the production term of $\mathrm{k}$ by the mean velocity gradients given as follows

$$
G=\mu_{t}\left(\frac{\partial U_{i}}{\partial x_{j}}+\frac{\partial U_{j}}{\partial x_{i}}\right) \frac{\partial U_{i}}{\partial x_{j}}
$$

The standard values of the constants $\mathrm{c}_{\mu}=0.09, \mathrm{c}_{1}=1.44, \mathrm{c}_{2}=1.92$ and the turbulent

Schmidt numbers for $\mathrm{k}$ and $\varepsilon, \sigma_{\mathrm{k}}=1.0$ and $\sigma_{\varepsilon}=1.3$, respectively, are used in the present computations.

The standard k- $\omega$ model [21] relates the eddy viscosity to $\mathrm{k}$ and to the turbulence frequency $(\omega)$. 
$\mu_{t}=\frac{k}{\omega}$

The $\mathrm{k}$ and $\omega$ are calculated from the following model transport equations

$$
\begin{aligned}
& \frac{\partial \rho k}{\partial t}+\frac{\partial \rho U_{j} k}{\partial x_{j}}=\frac{\partial}{\partial x_{j}}\left(\frac{\mu_{t}}{\sigma_{k}} \frac{\partial k}{\partial x_{j}}\right)+G-\rho \beta^{\prime} k \omega \\
& \frac{\partial \rho \omega}{\partial t}+\frac{\partial \rho U_{j} \omega}{\partial x_{j}}=\frac{\partial}{\partial x_{j}}\left(\frac{\mu_{t}}{\sigma_{\varepsilon}} \frac{\partial \omega}{\partial x_{j}}\right)+\alpha \frac{\omega}{k} G-\rho \beta \omega^{2}
\end{aligned}
$$

The standard values of the constants are $\beta^{\prime}=0.09, \alpha=5 / 9, \beta=3 / 40$ and the turbulent Schmidt numbers for $\mathrm{k}$ and $\omega, \sigma_{\mathrm{k}}=2$ and $\sigma_{\omega}=2$. The model is numerically stable, especially the low-Reynolds number version, as it tends to produce converged solutions more rapidly than the k- $\varepsilon$ model. Furthermore, the Low-Reynolds (LR) number version is more efficient than the LR k- $\varepsilon$ model in that it does not require calculations of wall distances, additional source term and/or damping functions based on the friction velocity. The main weakness of the $\mathrm{k}-\omega$ model is its strong sensitivity to free-stream conditions; Gebremedhin and $\mathrm{Wu}$ [22] applied the standard $\mathrm{k}-\omega$ model in an indoor environment together with four other turbulence models: namely (1) the standard $k-\varepsilon$ model, (2) the RNG k- $-\varepsilon$ model, (3) the Low-Reynolds Number k- $-\varepsilon$ model and (4) the Reynolds Stress Model (RSM). Based on convergence and computational stability criteria, they concluded that (a) the application of the standard k- $\omega$ model was not successful and (b) the RNG k- $\varepsilon$ model was found to be the most appropriate model to characterize the flow field of the ventilated space studied.

The SST k- $\omega$ based model [19] uses a blending function to combine the k- $\varepsilon$ and the k- $\omega$ models; in the near-wall region the k- $\omega$ model is activated, while for the rest of the flow the k- $\varepsilon$ model is used. By this approach, the attractive near-wall performance of the $\mathrm{k}-\omega$ model is utilized without the potential errors resulting from the free stream 
sensitivity of that model. Stamou and Katsiris [3] applied the SST k- $\omega$ based model for the first time in indoor environment; they calculated air - flow velocities and temperatures in a model office room. Calculations were compared with experiments and with the results of the standard k- $\varepsilon$, the RNG k- $\varepsilon$ model and the laminar model. It was concluded that (a) all the three tested turbulent models predict satisfactorily the main qualitative features of the flow and temperature fields and (b) computations with the SST k- $\omega$ based model showed the best agreement with measurements.

\subsection{Discretization and solution of the equations}

The finite control-volume method is implemented for the spatial discretisation of the domain. The continuity, momentum and energy equations are integrated over each control volume, such that the relevant quantity (mass, momentum, energy, $\mathrm{k}, \varepsilon$ and $\omega$ ) is conserved, in a discrete sense, for each control volume. For the continuity equation (pressure-velocity coupling) a second order central difference approximation is used, modified by a fourth order derivative in pressure, which redistributes the influence of pressure. The second order upwind Euler scheme approximates the transient term.

The code employs an automatic, unstructured hybrid element mesh generator with an adaptive mesh refinement algorithm, which permits a very accurate representation of the boundaries. The advantage of using unstructured mesh is the minimization of numerical errors and the consistency of the solution throughout the domain. For the solution of the equations, a scalable and fully implicit coupled solver is used. 


\section{The Galatsi Arena}

The Galatsi Arena is located in the district of Galatsi, about $8 \mathrm{~km}$ north of the Athens city centre and has a capacity of 6,000 spectators. The Arena, which measures $122.0 \mathrm{~m}$ long, $100.0 \mathrm{~m}$ wide and a maximum roof height of $30.0 \mathrm{~m}$, features a very interesting design. Its roof takes the dynamic shape of the wing of an airplane (see Figure 1), while the large glass surfaces make sure that its interior is filled with sunlight all day. The Arena was designed by A. Tobazis and built by EMPEDOS SA at a cost of $€ 43$ million, while construction works commenced in November 2001.

The premises are served by a variable air volume (VAV) air conditioning system; the temperature of the incoming air could be automatically regulated. The main airsupply and exhaust devices are shown in Figure 2. The air is delivered to the Arena via 256 jet nozzles, which are organized as follows: (1) 32 diffusers are mounted above the four entrances in the area of athletes in four series of 8 having a total capacity equal to $32 X 1,675=53,600 \mathrm{~m}^{3} / \mathrm{h}$, and (2) 224 diffusers are mounted in groups of 56 on the 4 air pipes in the roof of the Arena having a total capacity equal to $224 \mathrm{X} 1,005=225,120$ $\mathrm{m}^{3} / \mathrm{h}$. The angle of all the diffusers above the entrances was set equal to $28^{\circ}$ with the horizontal; a positive angle means that the jet faces upwards. The jets from the diffusers in the roof were facing towards the interior of the Arena or towards the outer walls for the ventilation of the space of the corridors; the angles of these jets were variable ranging from $-30^{\circ}$ to $+18^{\circ}$.

The air is extracted to the plenum via: (1) 32 square extract grilles on walls having a total capacity equal to $36,100 \mathrm{~m}^{3} / \mathrm{h}$, (2) 2,046 openings under 20 groups of the seats of a total capacity equal to $160,774 \mathrm{~m}^{3} / \mathrm{h}$ and (3) 57 floor openings (total capacity $=57,351$ 
$\mathrm{m}^{3} / \mathrm{h}$ ). The total outgoing air flow-rate is equal to $254,225 \mathrm{~m}^{3} / \mathrm{h}$. In the calculations the outlet flow was set equal to the incoming flow rate.

\section{Application of the model}

Calculations were performed for two scenarios of operation of the HVAC system, which corresponded to two values of temperatures of conditioned inlet air (a) $\mathrm{T}_{\mathrm{in}}=14^{\circ} \mathrm{C}$ and (b) $\mathrm{T}_{\mathrm{in}}=16^{\circ} \mathrm{C}$.

\subsection{Boundary conditions and the numerical grid}

In Figure 3 a view of (a) the real geometry and (b) the simulated geometry of the interior of the Arena are shown. Figure 3 depicts that the simulated model has almost the same geometrical configuration as the real Galatsi Arena.

Galatsi Arena was modeled with a normal occupancy of 6,000 persons. Existing furniture, supply-exhaust devices, lights etc. were included in the model with their approximated dimensions to simulate the real environment. The supply and exhaust boundary conditions were specified to summer conditions; the outdoor air temperature was set equal to $36.5^{\circ} \mathrm{C}$. The air flow-rates and the temperatures of the air supply diffusers and jets were set equal to their actual values, while at the extract grilles and openings the pressure was set equal to the atmospheric pressure.

Heat fluxes were modeled to represent the amount of heat generated by the occupants,

e.g. spectators and athletes, and the furniture in Galatsi Arena. Each simulated occupant was assumed to have a surface area of $1.6 \mathrm{~m}^{2}$ and was modeled to generate convective heat equal to $70.0 \mathrm{~W}$. This value corresponds to $43.7 \mathrm{~W} / \mathrm{m}^{2}$ [23]. At the walls, floor and 
ceiling of the Galatsi Arena the "radiation" condition has been applied, which does not require the specification of temperatures at these boundaries.

In Figure 4 a view of the numerical grid is shown; due to symmetry half of the Arena was modeled. The grid consisted of approximately 4,000,000 unstructured elements (tetrahedrals, prisms and pyramids) with grid refinement on the surface of the heat sources and in the inlet and outlet regions. A sensitivity analysis was conducted to ensure that the resolution of the mesh was not influencing the results. The construction of the 3-D geometry and the relevant grid was a difficult and time-consuming task; it was performed with the CAD software Rhinoceros [24] using as inputs the available 2$\mathrm{D}$ architectural and mechanical engineering CAD drawings of the Arena.

To reduce the total computation time the initial air temperatures were set equal to the values determined by a simple heat balance assuming that the Arena is a completely mixed reactor; these values were calculated equal to $23.52^{\circ} \mathrm{C}$ and $25.08^{\circ} \mathrm{C}$ for $\mathrm{T}_{\text {in }}=14^{\circ} \mathrm{C}$ and $16^{\circ} \mathrm{C}$, respectively.

\section{$5 \quad$ Results and discussion}

\subsection{Air velocities and temperatures}

In Figure 5 calculated flow velocities (arrows on separate equidistant grids) for $T_{i n}=16^{\circ} \mathrm{C}$ at two vertical planes $y z$ at (a) $x=10.0 \mathrm{~m}$ and (b) $\mathrm{x}=30 \mathrm{~m}$, respectively, are shown. In Figure 6 velocity contours are shown at a horizontal plane $\mathrm{xy}$ and $\mathrm{z}=1.0 \mathrm{~m}$ for (a) $\mathrm{T}_{\text {in }}=14^{\circ} \mathrm{C}$ and (b) $\mathrm{T}_{\mathrm{in}}=16^{\circ} \mathrm{C}$, respectively. In Figure 7 the calculated air temperature contours are shown, which correspond to the flow field of Figure 5; for comparison purposes the corresponding temperature contours for $\mathrm{T}_{\mathrm{in}}=14^{\circ} \mathrm{C}$ are shown in Figure 8 . Moreover, in Figure 9 the temperature contours, which correspond to the flow fields of 
Figure 6, are plotted. In Table 1 the values (ranges and average values) of the calculated air velocities and temperatures are shown in the areas if interest; these are the area of the athletes and three main areas of spectators: (1) lower: from the $1^{\text {st }}$ to the $6^{\text {th }}$ row of seats, (2) middle: from the $7^{\text {th }}$ to the $12^{\text {th }}$ row and (3) upper: from the $13^{\text {th }}$ row to the last $\left(17^{\text {th }}\right)$ row of seats; these areas were further divided in three sectors: Northern, Eastern and Western. Due to symmetry the areas of seats in the Southern sector are expected to have the same characteristics with the Northern sector.

Figures 5 to 9 show that the flow field in the Galatsi Arena is very complicated; this is due mainly to the interaction of the incoming airflow from the 256 diffusers with the buoyant plumes originating from the 6,000 occupants, who constitute a significant heat source in the Arena. Figure 5 depicts that the heavy airflow from the diffusers in the roof of the Arena is directed downwards, where it joins the airflows from the diffusers above the entrances; the resulting flow is subsequently "lifted"; then, is descends to lower levels and finally it is directed to the outlet openings. The air velocities decrease as the flow progresses downwards. Practically, the above-mentioned flow forms a clockwise recirculation region, which occupies a large part of the Arena; in the area of athletes almost completely mixed conditions are created. Two recirculation regions are also formed in the areas of corridors from the airflows of the diffusers in the roof of the Arena, which are directed towards the inner walls.

Figures 6, 7, 8 and 9 depict that the temperature field depends on the flow field and vice-versa. In spite of the approximately complete mixed regime in a large part of the Arena, the distributions of temperature in Figures 7 and 8 show a general tendency to stratify; this tendency is interrupted locally by the airflows originating from the 
diffusers (mainly from these above the entrances), which create "islands" of regions with low air temperatures.

In the areas of the spectators air velocities range from $0.08 \mathrm{~m} / \mathrm{sec}$ up to $0.64 \mathrm{~m} / \mathrm{sec}$ for $\mathrm{T}_{\mathrm{in}}=14^{\circ} \mathrm{C}$ and from $0.08 \mathrm{~m} / \mathrm{sec}$ up to $0.48 \mathrm{~m} / \mathrm{sec}$ for $\mathrm{T}_{\mathrm{in}}=16^{\circ} \mathrm{C}$; in some regions air velocities are much higher than the recommended limit of less than $0.25 \mathrm{~m} / \mathrm{s}$ by the ISO Standard 7730 [25]. The ranges of air temperatures are calculated equal to $22-26^{\circ} \mathrm{C}$ and $24-27^{\circ} \mathrm{C}$ for $\mathrm{T}_{\mathrm{in}}=14^{\circ} \mathrm{C}$ and $\mathrm{T}_{\mathrm{in}}=16^{\circ} \mathrm{C}$, respectively; low values of air temperatures are noticed in the eastern sector of the Arena.

In the area of the athletes air velocities range from $0.10 \mathrm{~m} / \mathrm{sec}$ to $0.80 \mathrm{~m} / \mathrm{sec}$. The regions with high air drafts were identified and indicated to the organizers of the Games, because these may affect the motion of (a) the ball of the table tennis or (b) the ribbon of the rhythm gymnastics. The air temperatures are practically uniformly distributed in the area of the athletes due to the relatively high level of mixing; they range from $22^{\circ} \mathrm{C}$ to $24^{\circ} \mathrm{C}$ and from $24^{\circ} \mathrm{C}$ to $26^{\circ} \mathrm{C}$ for $\mathrm{T}_{\text {in }}=14^{\circ} \mathrm{C}$ and $\mathrm{T}_{\text {in }}=16^{\circ} \mathrm{C}$, respectively.

\subsection{Thermal comfort}

ISO 7730 [25] defines thermal comfort as "the condition of mind that expresses satisfaction with the thermal environment". The reference to "mind" emphasises that comfort is a psychological phenomenon; therefore, it is "measured" using subjective methods. Over many years empirical research has related environmental conditions to physiological and subjective responses of subjects. Nowadays, the thermal comfort indices Predicted Mean Vote (PMV) and Predicted Percentage of Dissatisfied (PPD) of Fanger [26] are accepted as ISO 7730 [25]; these are calculated by two empirical 
equations. The PMV equation uses a steady-state heat balance for the human body and postulates a link between the deviation from the minimum load on heat balance effector's mechanisms, e.g. sweating, vaso-constriction, vaso-dilation, and thermal comfort vote; the greater the load, the more the comfort vote deviates from zero. The basis of this equation was obtained from experiments, in which the thermal sensation vote indicated the personally experienced deviation to the heat balance $(-3$ [cold] to +3 [hot]; seven point scale, $0=$ neutral (optimum)). The PPD equation indicates the variance in the thermal sensation of the group of persons exposed to the same conditions. Dissatisfaction with the thermal environment, discomfort, was defined for those who voted cool $(-2)$, cold $(-3)$, warm $(+2)$ or hot $(+3)$. Under optimal thermal conditions (PMV $=0)$ a minimum of $5 \%$ dissatisfied is found, assuming identical activity levels, clothing and environmental conditions.

The PMV and PPD are calculated from knowledge of the so-called six basic variables: (1) activity, (2) clothing and (3) four environmental variables: air temperature, air velocity, mean radiant temperature and air humidity. Generally, the value of the PMV is very sensitive to the air temperature; the effect of the metabolism on PMV is also pronounced. In the present work the values of the variables for the activity (metabolic rate) and the clothing (ensemble insulation) were determined using ASHRAE Fundamentals [27]; more specifically, the total thermal resistance of clothing was taken equal to $0.5 \mathrm{clo}$ (i.e. $0.078 \mathrm{~m}^{2}{ }^{\circ} \mathrm{K} / \mathrm{W}$ ) and the metabolic rate of the spectators equal to 1.2 met (i.e. $70 \mathrm{~W} / \mathrm{m}^{2}$ ). The environmental variables were determined from the $\mathrm{CFD}$ calculations. The mean radiant temperature was calculated equal to $24.62^{\circ} \mathrm{C}$ and $26.11^{\circ} \mathrm{C}$ for $\mathrm{T}_{\mathrm{in}}=14^{\circ} \mathrm{C}$ and $16^{\circ} \mathrm{C}$, respectively. The mean values of the air temperature and velocity in the areas of interest, which are shown in Table 1, were used in the 
calculation of the comfort indices. An EXCEL spreadsheet was formulated for the calculation of PMV and PPD indices in the areas of interest; these values are shown in Table 2.

The figures of Table 2 show that for $\mathrm{T}=14^{\circ} \mathrm{C}$ the thermal conditions are not satisfactory. The low-negative values of PMV (almost in all rows of seats PMV<-0.5) indicate that the air temperatures are lower than the desired values; the percentage of the occupants who are expected to express dissatisfaction ranges from $8.4 \%$ to $27.4 \%$. For $\mathrm{T}=16^{\circ} \mathrm{C}$ the relatively high air velocities (up to $0.40 \mathrm{~m} / \mathrm{sec}$ ) are combined with the relatively high temperatures (up to $26.5^{\circ} \mathrm{C}$ ); the desired range of temperatures is 24 $\left.26^{\circ} \mathrm{C}[25]\right)$ to create thermal conditions which are generally pleasant; PPD values show that less than $7 \%$ of the spectators are expected to express dissatisfaction. In the area of athletes air temperatures for $\mathrm{T}=14^{\circ} \mathrm{C}$ are low $\left(22-24^{\circ} \mathrm{C}\right)$, while for $\mathrm{T}=16^{\circ} \mathrm{C}$ are very satisfactory $\left(24-26^{\circ} \mathrm{C}\right)$; moreover, the relatively high air drafts generally create to the athletes a feeling of freshness.

In the present work the factor of humidity was not considered, because people are quite insensitive to humidity levels over a wide humidity range - at the temperatures, which are normally found in air-conditioned spaces. Furthermore, the effect on comfort of a shift in humidity may be compensated for by a small adjustment of air temperature; for example, higher humidity makes a person feel warmer, thus a slight lowering of temperature will compensate for the comfort effect of this higher humidity.

\section{Conclusions}

CFD calculations in the Galatsi Arena demonstrated that that the variable air volume conditioning system serving the Galatsi Arena is capable to ensure satisfactory 
thermal conditions for the spectators. Calculated PMV and PPD values showed that thermal conditions in the Arena are very satisfactory for $\mathrm{T}_{\mathrm{in}}=16^{\circ} \mathrm{C}$; only a small percentage of less than $7 \%$ of the spectators is expected to be slightly uncomfortable. The temperature of $\mathrm{T}_{\mathrm{in}}=16^{\circ} \mathrm{C}$ was proposed for application during the Olympic Games “Athens 2004". Moreover, the regions with high air drafts in the areas of athletes were identified and indicated to the organizers of the Games.

\section{Acknowledgments}

This work is a part of a Research Project: "Evaluation and improvement of the Indoor Conditions (safety, air quality and comfort) in the Indoor Stadiums and Amphitheaters of the Olympic Games Athens-2004 with the use of Mathematical Models”, 2003-2004, which was financed by the Ministry of Culture (General Secretariat for the Olympic Games 2004). The authors would like to thank the Ministry of Culture; especially the former General Secretary Prof. C. Kartalis. Thanks are also due to all the scientists, who provided information on the Galatsi Arena.

\section{References}

[1] M. Bojic, F. Yik and T. Y. Lo, Locating air-conditioners and furniture inside residential flats to obtain good thermal comfort, Energy and Buildings 34 (7) 2002, 745 751.

[2] W. N. Hien, W. Liping, A. N. Chandra, A. R. Pandey and W. Xiaolin, Effects of double glazed facade on energy consumption, thermal comfort and condensation for a typical office building in Singapore, Energy and Buildings 37(6) (2005) 563-572. 
[3] A. Stamou and I. Katsiris, Verification and application of a CFD model for the evaluation of thermal comfort in office spaces, Building and Environment 41 (2006) $1171-1181$.

[4] K. A. Papakonstantinou, C. T. Kiranoudis and N. C. Markatos, Computational analysis of thermal comfort: the case of the archaeological museum of Athens, Applied Mathematical Modelling 24(7) (2000) 477-494.

[5] K. W. D. Cheong, E. Djunaedy, Y. L. Chua, K. W. Tham, S. C. Sekhar, N. H. Wong and M. B. Ullah, Thermal comfort study of an air-conditioned lecture theatre in the tropics, Building and Environment 38(1) (2003) 63-73.

[6] T. Karimipanah, H. B. Awbi, M. Sandberg and C. Blomqvist, Investigation of air quality, comfort parameters and effectiveness for two floor-level air supply systems in classrooms, Building and Environment 42(2) 2007 647-655.

[7] C. G. Helmis, J. Tzoutzas, H. A. Flocas, C. H. Halios, O. I. Stathopoulou, V.D. Assimakopoulos, V. Panis, M. Apostolatou, G. Sgouros and E. Adam, Indoor air quality in a dentistry clinic, Science of The Total Environment 377(2-3) 2007 349-365.

[8] P. Rohdin and B. Moshfegh, Numerical predictions of indoor climate in large industrial premises, A comparison between different $\mathrm{k}-\varepsilon$ models supported by field measurements. Building and Environment (In Press) doi:10.1016/j.buildenv.2006.11.005.

[9] W. K. Chow, Numerical studies of airflows induced by mechanical ventilation and air-conditioning (MVAC) systems, Applied Energy 68(2) 2001 135-159.

[10] T. Z. Desta, A. Van Brecht, J. Meyers, M. Baelmans and D. Berckmans, Combining CFD and data-based mechanistic (DBM) modeling approaches, Energy and Buildings 36 (6) (2004) 535-542 
[11] Z. Zhai and Q. Chen, Sensitivity analysis and application guides for integrated building energy and CFD simulation, Energy and Building 38 (9) (2006) 1060-1068. [12] T. Kim, D. Song, S. Kato and S. Murakami, Two-step optimal design method using genetic algorithms and CFD-coupled simulation for indoor thermal environments, Applied Thermal Engineering 27(1) (2007) 3-11.

[13] FLUENT News, Spring 2001.

[14] M. Chown et al, The Olympic ice hockey stadium, Turin, Italy, The Arup Journal, 41 (1) 2006 41-46.

[15] ISO 7730, Moderate Thermal Environments - Determination of the PMV and PPD Indices and Specification of the Conditions for Thermal Comfort, 2nd edn. International Standards Organisation, Geneva, ref no ISO 7730:1994(E).

[16] PHOENICS 3.2 (software package), CHAM, London, UK, 1999.

[17] FLUENT Inc., Fluent user's guide, Version 5.0, Lebanon, NH, USA, 1998.

[18] ANSYS Inc., CFX-5.6 User Guide, Harwell, Didcot, Oxfordshire, OX110RA, UK, Website: http://www.ansys.com/cfx, 2003.

[19] F. R. Menter, Two-equation eddy viscosity turbulence models for engineering applications, AIAA J. 32(8) (1994) 269-289.

[20] W. Rodi, Turbulence Models and Their Application in Hydraulics -A State of the Art Review, IAHR, Delft, The Netherlands, 1980.

[21] D. C. Wilcox, Reassessment of the scale determining equation for advanced turbulence models, AIAA J. 26(11) (1988) 1299-1311.

[22] K. G. Gebremedhin and B. X. Wu, Characterization of flow field in a ventilated space and simulation of heat exchange between cows and their environment, Journal of Thermal Biology 28(4) (2003) 301-319. 
[23] ASHRAE, ASHRAE Standard 55-1992R, Thermal environmental conditions for human occupancy, American Society of Heating Refrigerating and Air-conditioning Engineers, Inc., Atlanta, Georgia, USA, 2001.

[24] Rhinoceros, http://www.rhino3d.com/.

[25] ISO Standard 7730, Moderate thermal environments—-determination of the PMV and PPD indices and specifications of the conditions for thermal comfort, Geneva: International Organization for Standardization, 1994.

[26] P. O. Fanger, Thermal Comfort, 1st edn, McGraw-Hill Book Co, New York, 1970.

[27] ASHRAE, ASHRAE Handbook Fundamentals, American Society of Heating Refrigerating and Air Conditioning Engineers, Atlanta, USA, 1997. 


\section{ACCEPTED MANUSCRIPT}

\section{Figure legends}

Figure 1. View of the Galatsi Arena (www.stadia.gr)

Figure 2. View of a part of the interior of the Galatsi Arena with the main air-supply and exhaust devices

Figure 3. View of the interior of the Galatsi Arena

Figure 4. View of the numerical grid

Figure 5. Flow velocities at the level $\mathrm{yz}$ and (a) $\mathrm{x}=10.0 \mathrm{~m}$ and (b) $\mathrm{x}=30.0 \mathrm{~m}$ for $\mathrm{T}=16^{\circ} \mathrm{C}$

Figure 6. Flow velocities at a horizontal plane $x y$ and $z=1.0 \mathrm{~m}$ for (a) $\mathrm{T}=14^{\circ} \mathrm{C}$ and (b)

$\mathrm{T}=16^{\circ} \mathrm{C}$

Figure 7. Temperature contours $\left({ }^{\circ} \mathrm{C}\right.$ ) at the plane $\mathrm{yz}$ and (a) $\mathrm{x}=10.0 \mathrm{~m}$ and $(\mathrm{b}) \mathrm{x}=30.0 \mathrm{~m}$ for $\mathrm{T}=16^{\circ} \mathrm{C}$

Figure 8 . Temperature contours $\left({ }^{\circ} \mathrm{C}\right.$ ) at the plane $\mathrm{yz}$ and (a) $\mathrm{x}=10.0 \mathrm{~m}$ and (b) $\mathrm{x}=30.0 \mathrm{~m}$ for $\mathrm{T}=14^{\circ} \mathrm{C}$

Figure 9. Temperature contours at a horizontal plane $\mathrm{xy}$ and $\mathrm{z}=1.0 \mathrm{~m}$ for (a) $\mathrm{T}=14^{\circ} \mathrm{C}$ and

(b) $\mathrm{T}=16^{\circ} \mathrm{C}$ 


\section{ACCEPTED MANUSCRIPT}

Table 1. Calculated air velocities $(\mathrm{m} / \mathrm{sec})$ and temperatures $\left({ }^{\circ} \mathrm{C}\right)$

\begin{tabular}{lllll}
\hline $\mathrm{T}_{\text {in }}$ & $14^{\circ} \mathrm{C}$ & $14^{\circ} \mathrm{C}$ & $16^{\circ} \mathrm{C}$ & $16^{\circ} \mathrm{C}$ \\
\hline Area-Sector & Velocity & Temperature & Velocity & Temperature \\
\hline Lower-Southern & $0.08-0.48(0.35)$ & $23-25(24.0)$ & $0.16-0.48(0.35)$ & $25-27(26.0)$ \\
\hline Middle-Southern & $0.16-0.64(0.40)$ & $23-26(24.5)$ & $0.16-0.32(0.20)$ & $26-27(26.5)$ \\
\hline Upper-Southern & $0.16-0.48(0.35)$ & $23-26(24.5)$ & $0.16-0.48(0.35)$ & $26-27(26.5)$ \\
\hline Lower- Western & $0.08-0.64(0.25)$ & $23-25(23.5)$ & $0.16-0.48(0.30)$ & $24-26(25.0)$ \\
\hline Middle-Western & $0.16-0.48(0.40)$ & $23-25(23.5)$ & $0.16-0.48(0.40)$ & $24-26(25.5)$ \\
\hline Upper-Western & $0.08-0.32(0.30)$ & $24-26(25.0)$ & $0.08-0.48(0.25)$ & $26-27(26.5)$ \\
\hline Lower-Eastern & $0.16-0.64(0.40)$ & $22-25(23.0)$ & $0.08-0.32(0.20)$ & $24-26(25.0)$ \\
\hline Middle-Eastern & $0.16-0.64(0.50)$ & $22-25(23.5)$ & $0.08-0.48(0.30)$ & $24-27(25.5)$ \\
\hline Upper-Eastern & $0.16-0.48(0.30)$ & $22-26(24.5)$ & $0.08-0.32(0.20)$ & $25-27(26.0)$ \\
\hline
\end{tabular}


Table 2. Calculated values of PMV and PPD

\begin{tabular}{lcccl}
\hline $\mathrm{T}_{\text {in }}$ & $14^{\circ} \mathrm{C}$ & $14^{\circ} \mathrm{C}$ & $16^{\circ} \mathrm{C}$ & $16^{\circ} \mathrm{C}$ \\
\hline Area-Sector & PMV & PPD & PMV & PPD \\
\hline Lower-Southern & -0.71 & 15.5 & -0.05 & 5.1 \\
\hline Middle-Southern & -0.66 & 14.1 & +0.26 & 6.5 \\
\hline Upper-Southern & -0.59 & 12.4 & +0.07 & 5.1 \\
\hline Lower- Western & -0.64 & 13.6 & -0.22 & 6.0 \\
\hline Middle-Western & -0.90 & 22.2 & -0.24 & 6.1 \\
\hline Upper-Western & -0.40 & 8.4 & +0.19 & 5.7 \\
\hline Lower-Eastern & -1.03 & 27.2 & -0.04 & 5.0 \\
\hline Middle-Eastern & -1.03 & 27.4 & -0.10 & 5.2 \\
\hline Upper-Eastern & -0.52 & 10.6 & +0.16 & 5.5 \\
\hline
\end{tabular}




\section{ACCEPTED MANUSCRIPT}

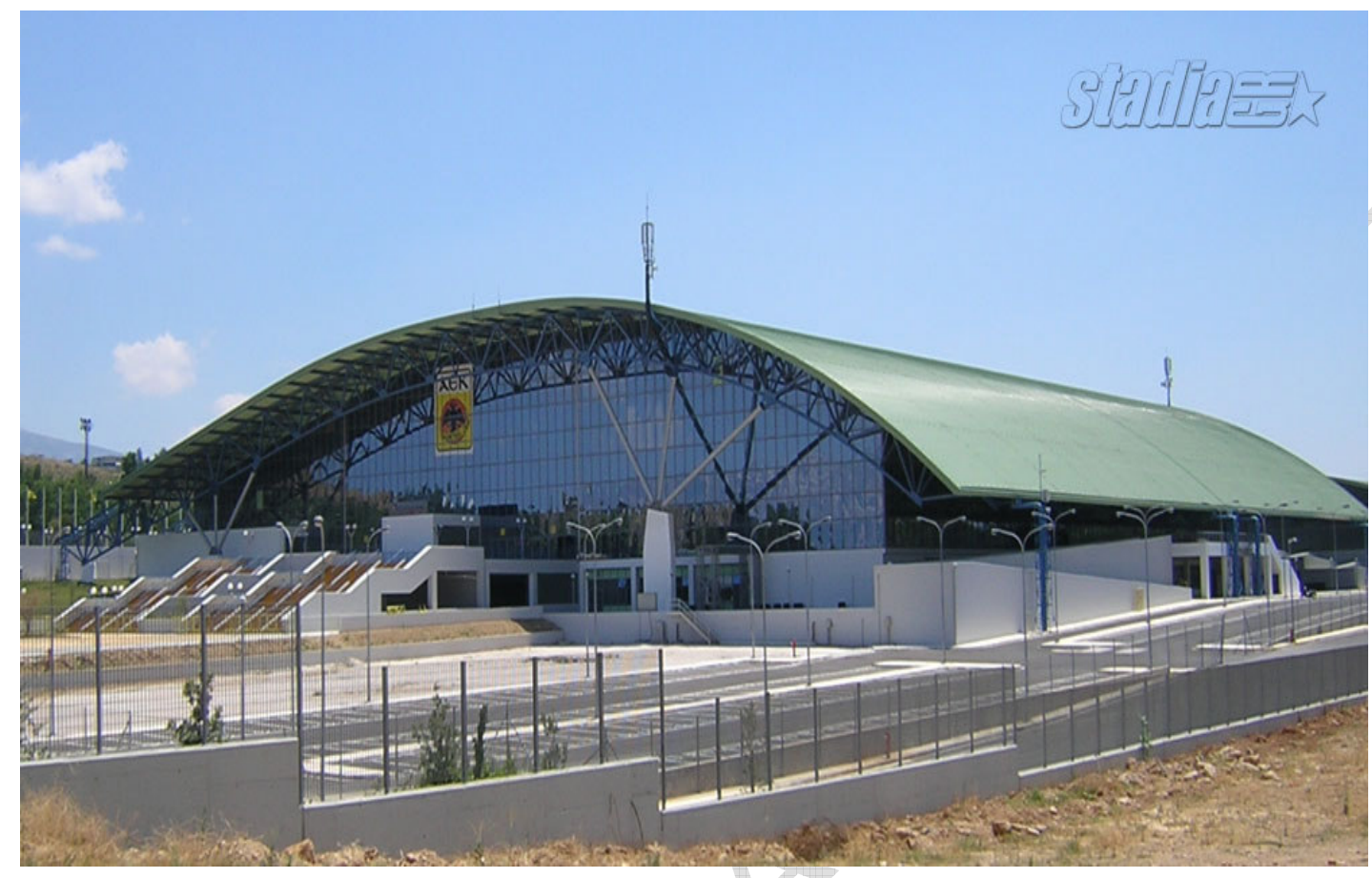

Figure 1 


\section{ACCEPTED MANUSCRIPT}

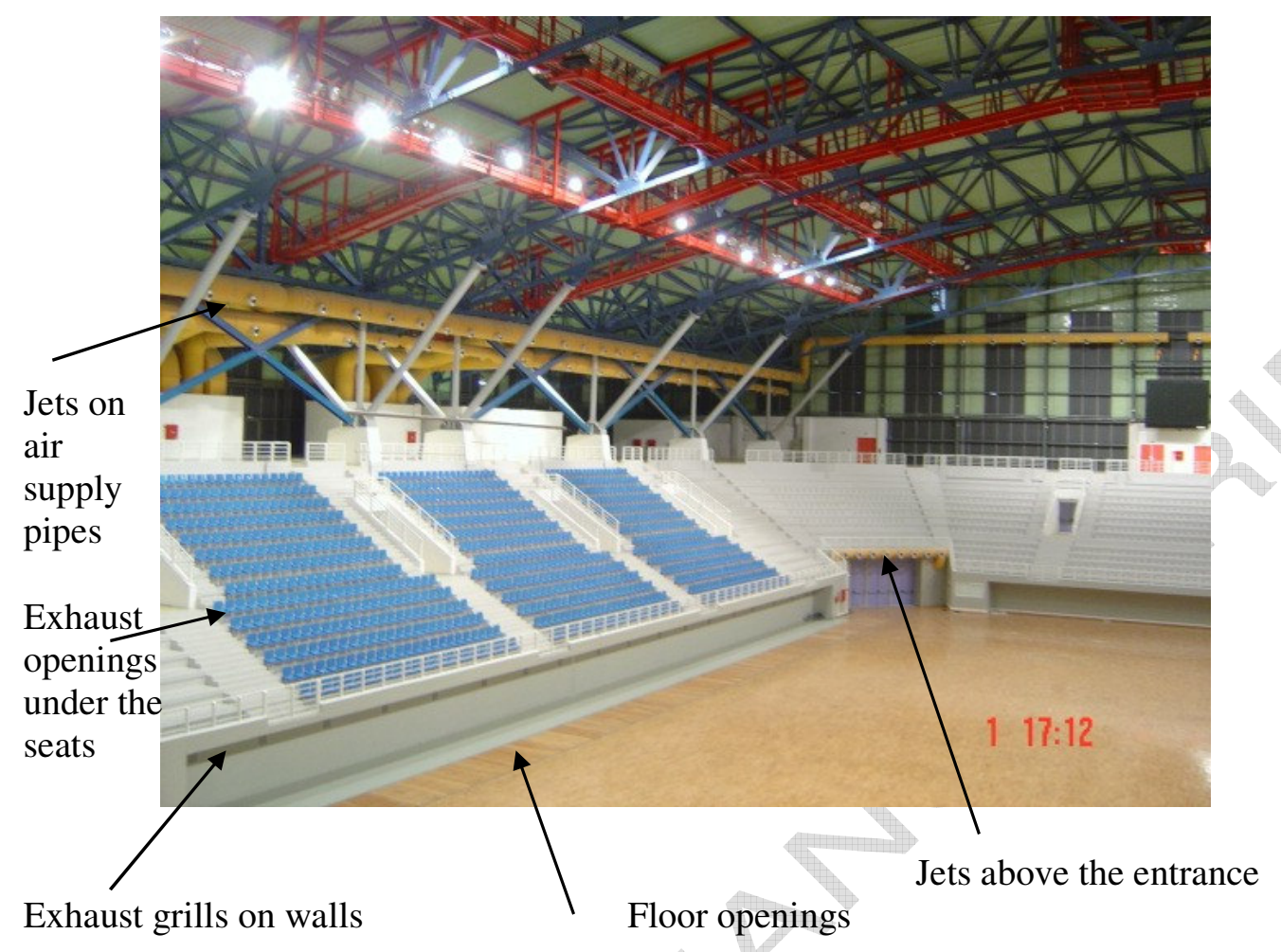

Figure 2 


\section{ACCEPTED MANUSCRIPT}

Figure 3

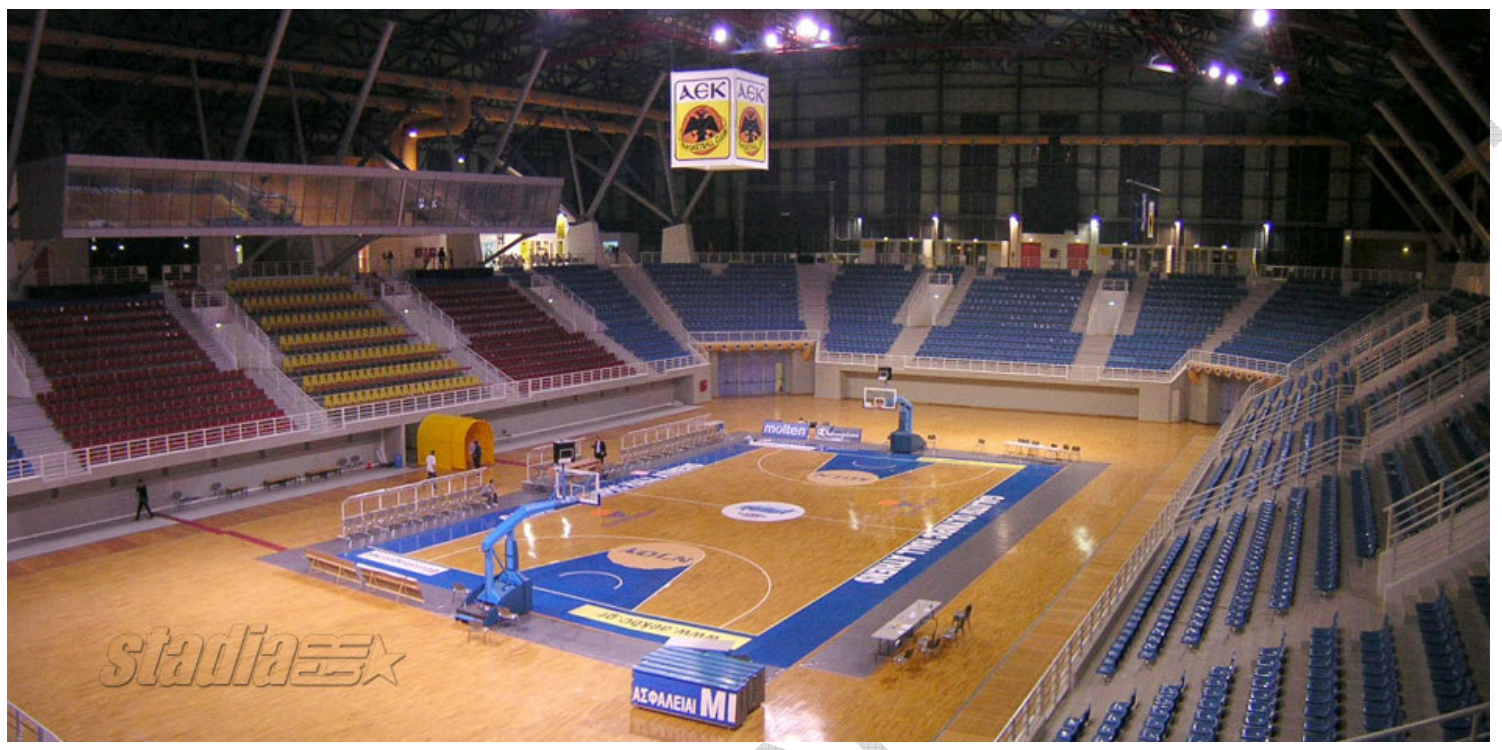

(a) The real geometry (www.stadia.gr)

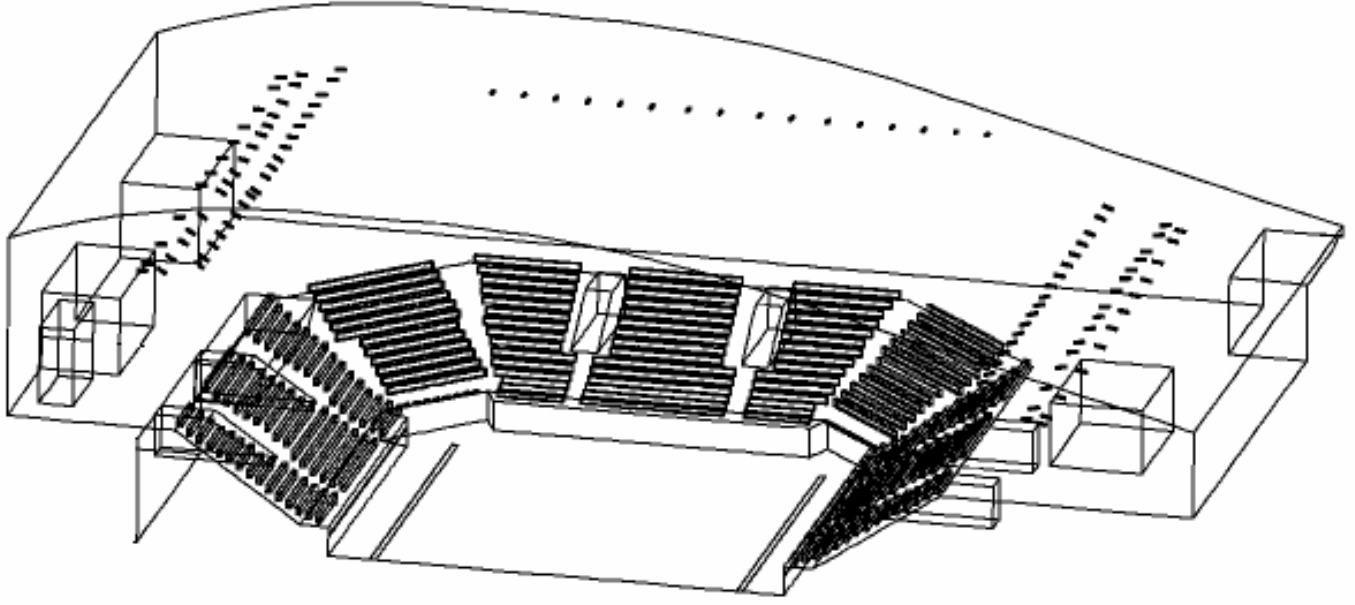

(b) The simulated geometry 


\section{ACCEPTED MANUSCRIPT}

Figure 4

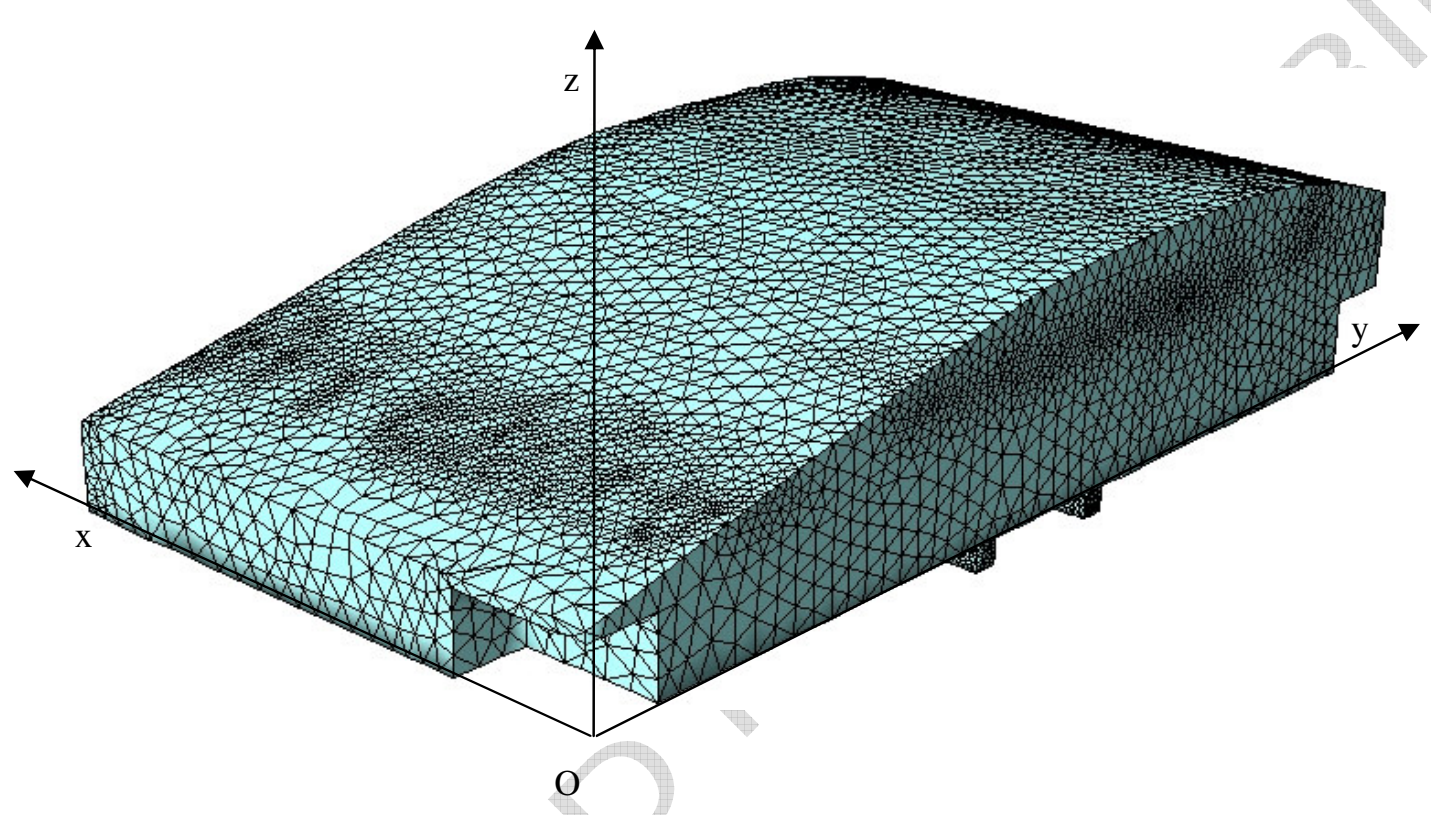




\section{ACCEPTED MANUSCRIPT}

Figure 5

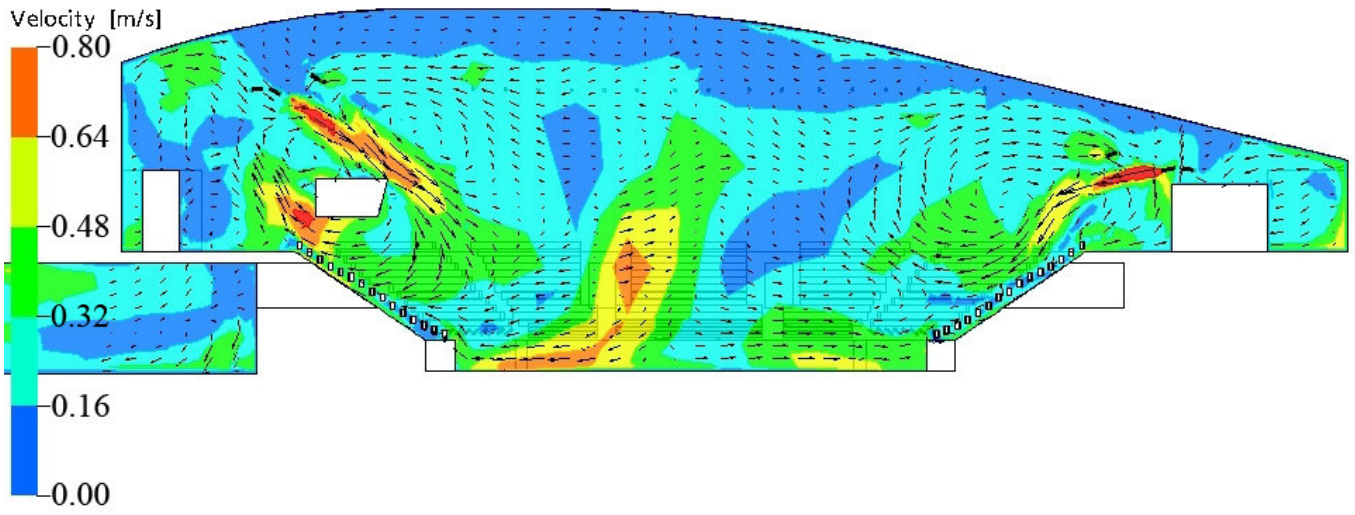

(a) $\mathrm{x}=10.0 \mathrm{~m}$

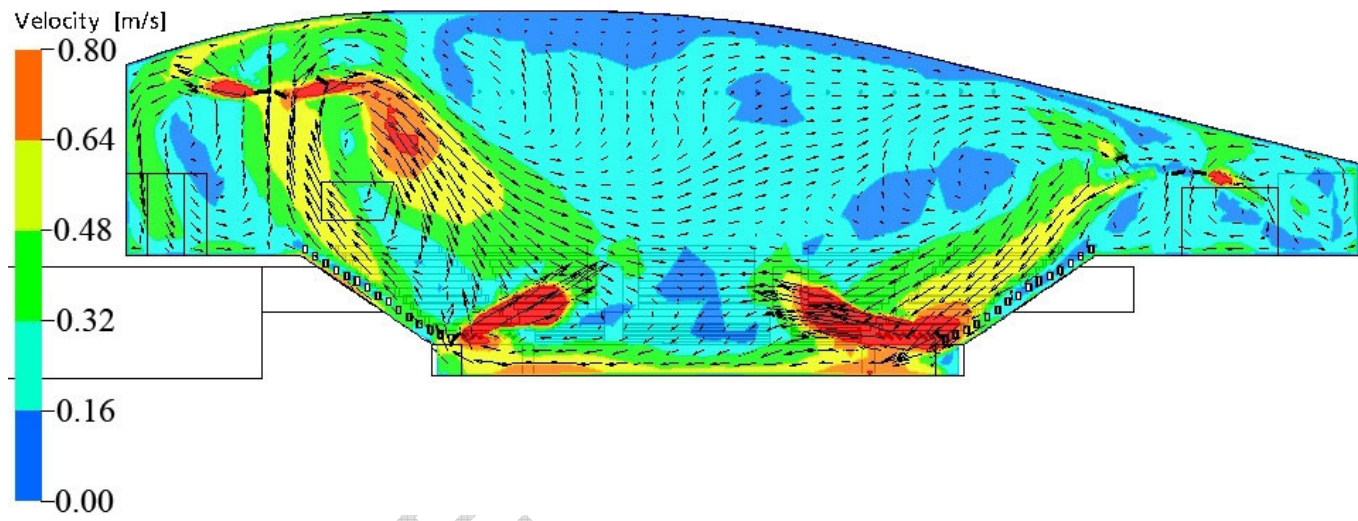

(b) $x=30.0 \mathrm{~m}$ 
Figure 6

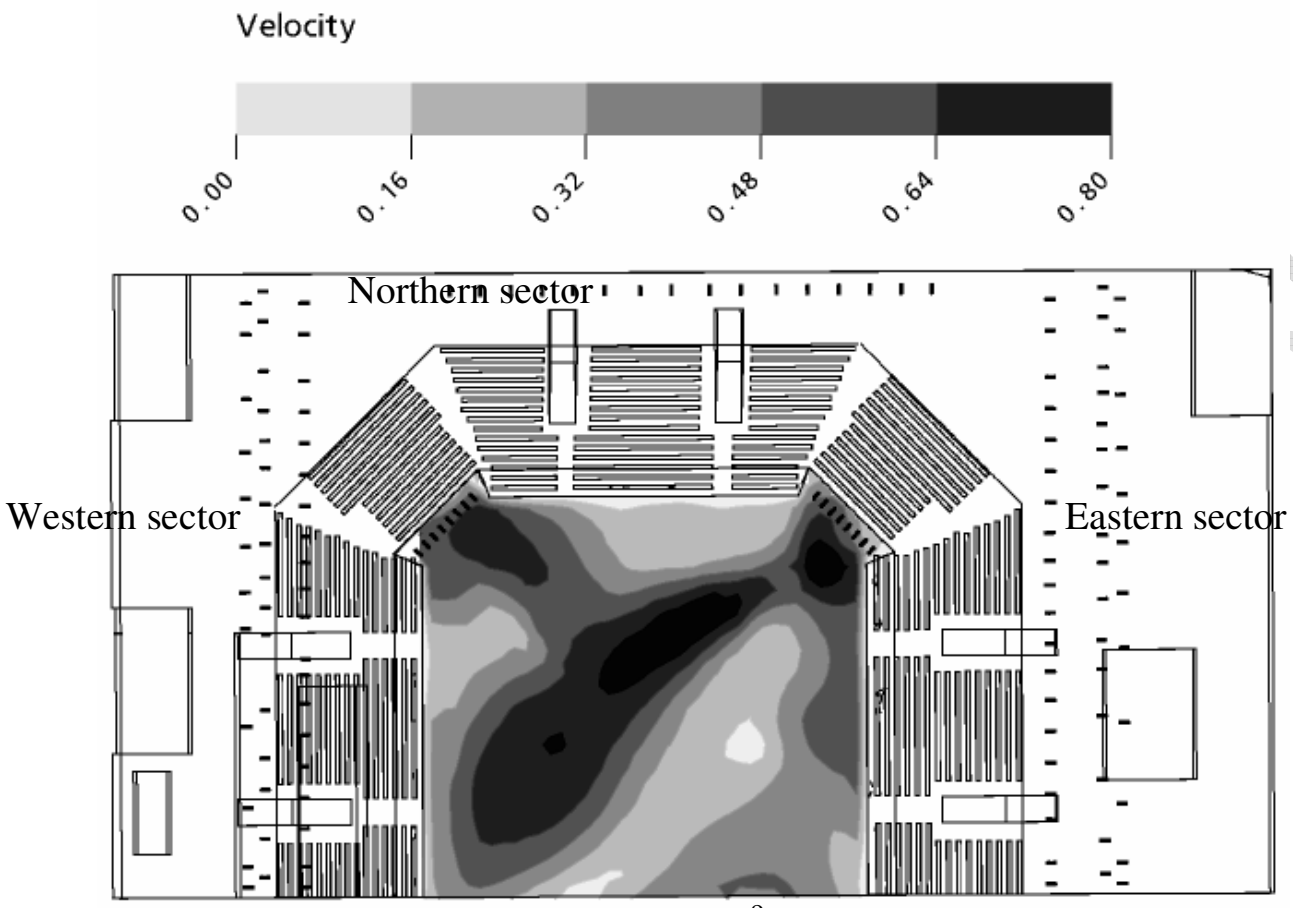

(a) $\mathrm{T}=14^{\circ} \mathrm{C}$

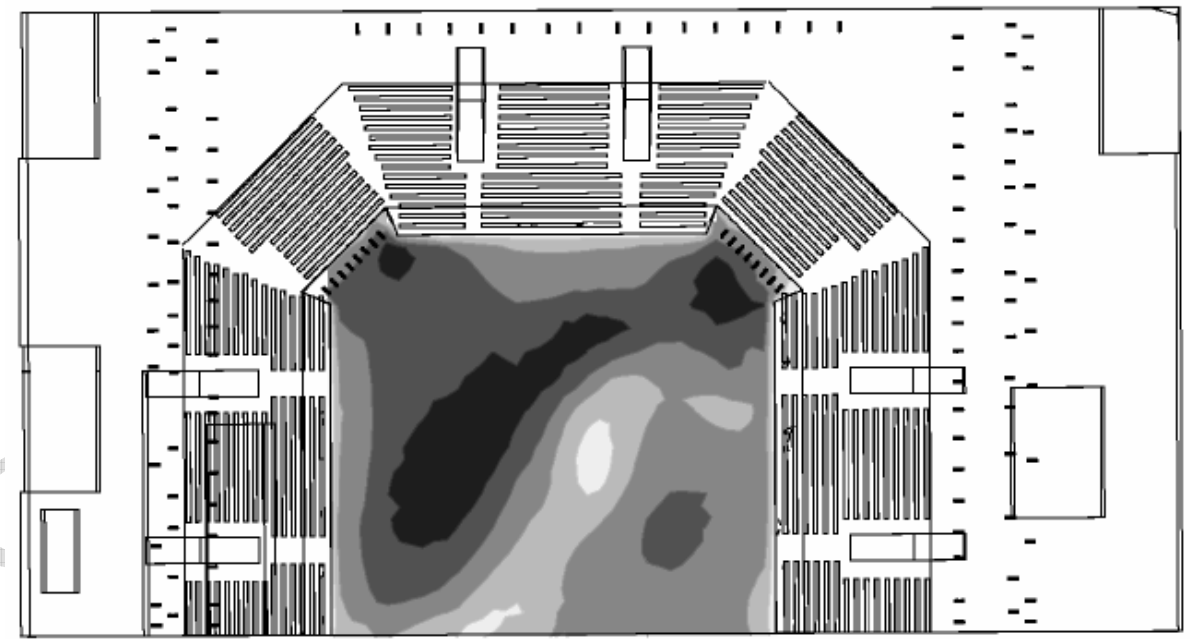

(b) $\mathrm{T}=16^{\circ} \mathrm{C}$ 


\section{ACCEPTED MANUSCRIPT}

Figure 7

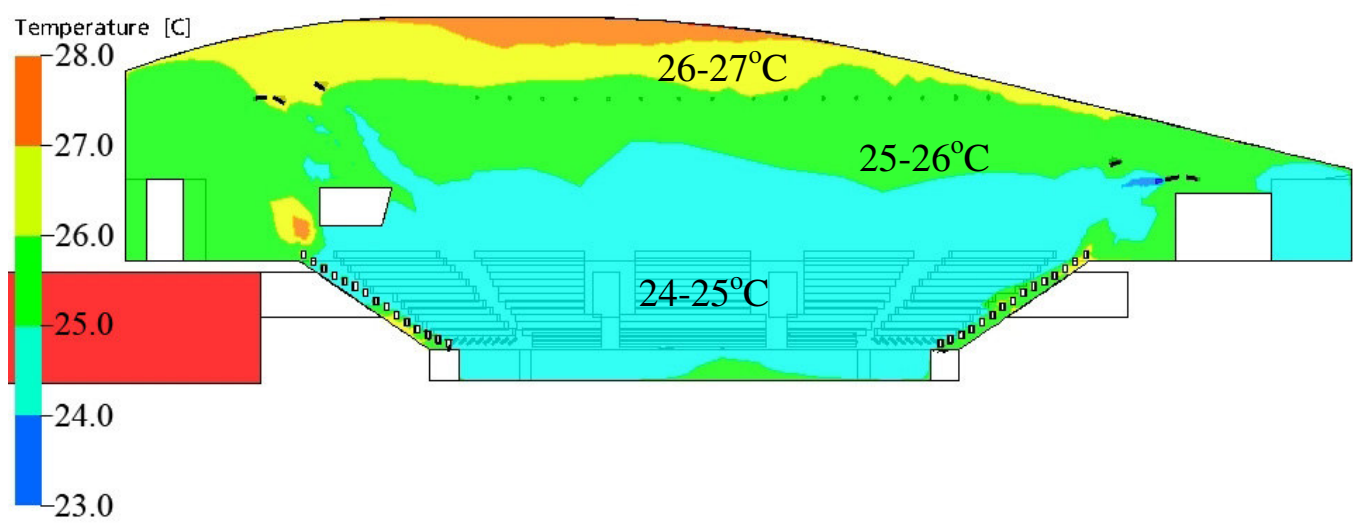

(a) $\mathrm{x}=10.0 \mathrm{~m}$

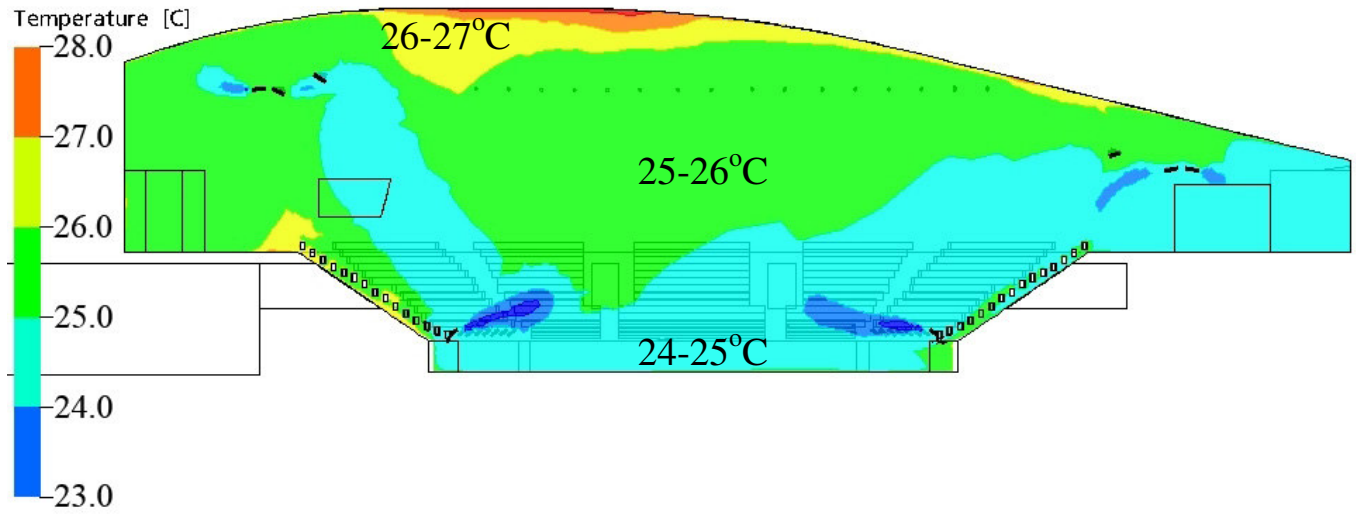

(b) $x=30.0 \mathrm{~m}$ 


\section{ACCEPTED MANUSCRIPT}

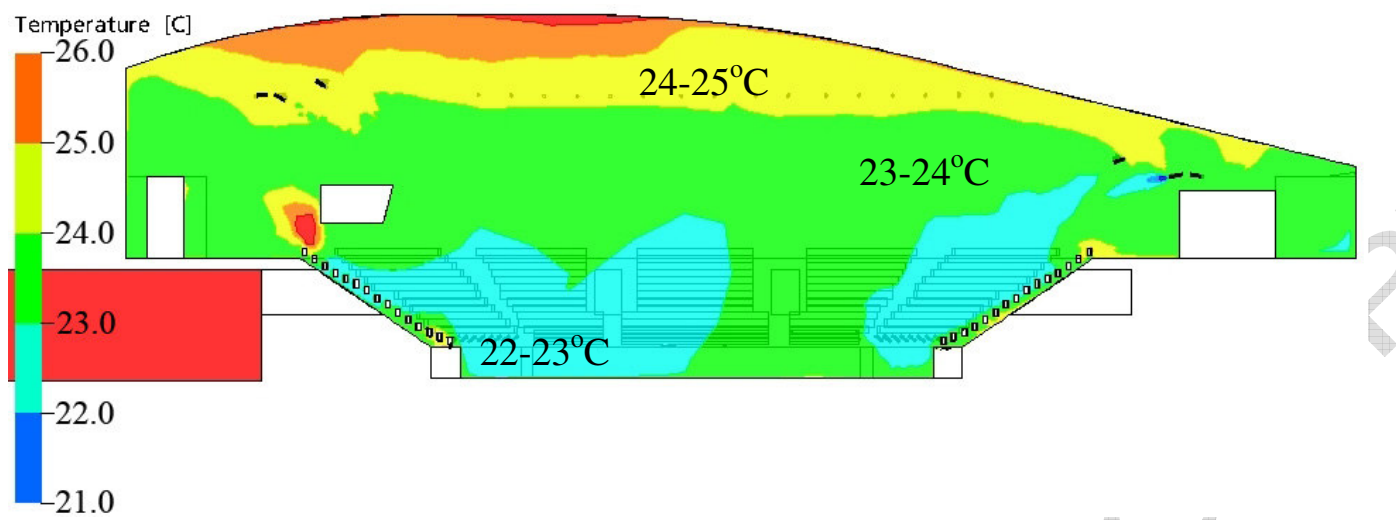

(a) $x=10.0 \mathrm{~m}$

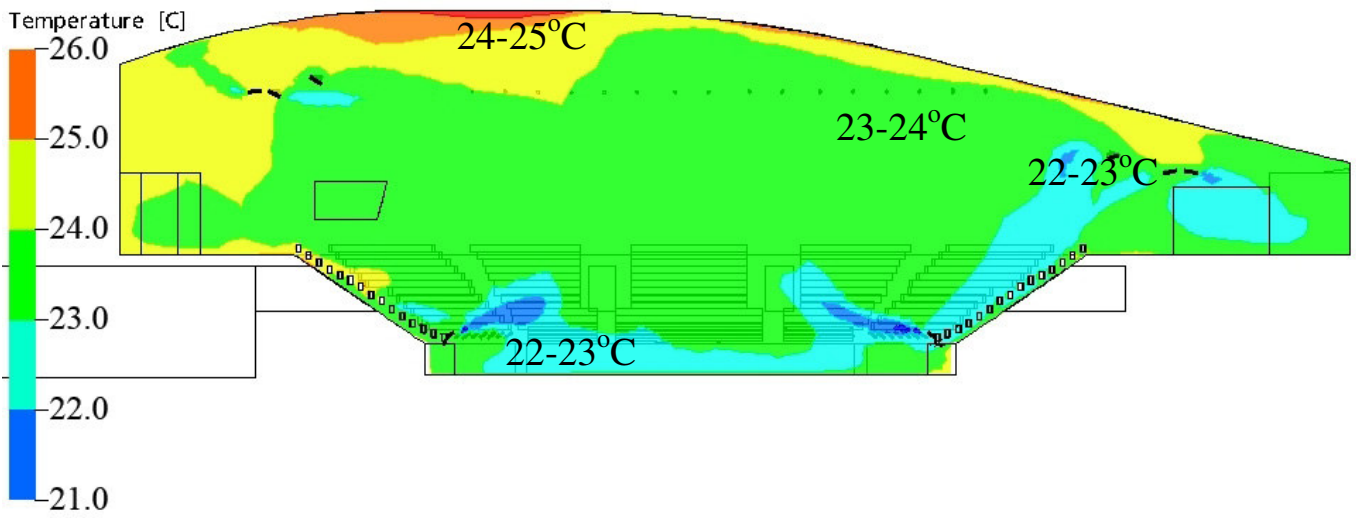

(b) $x=30.0 \mathrm{~m}$

Figure 8 
Temp

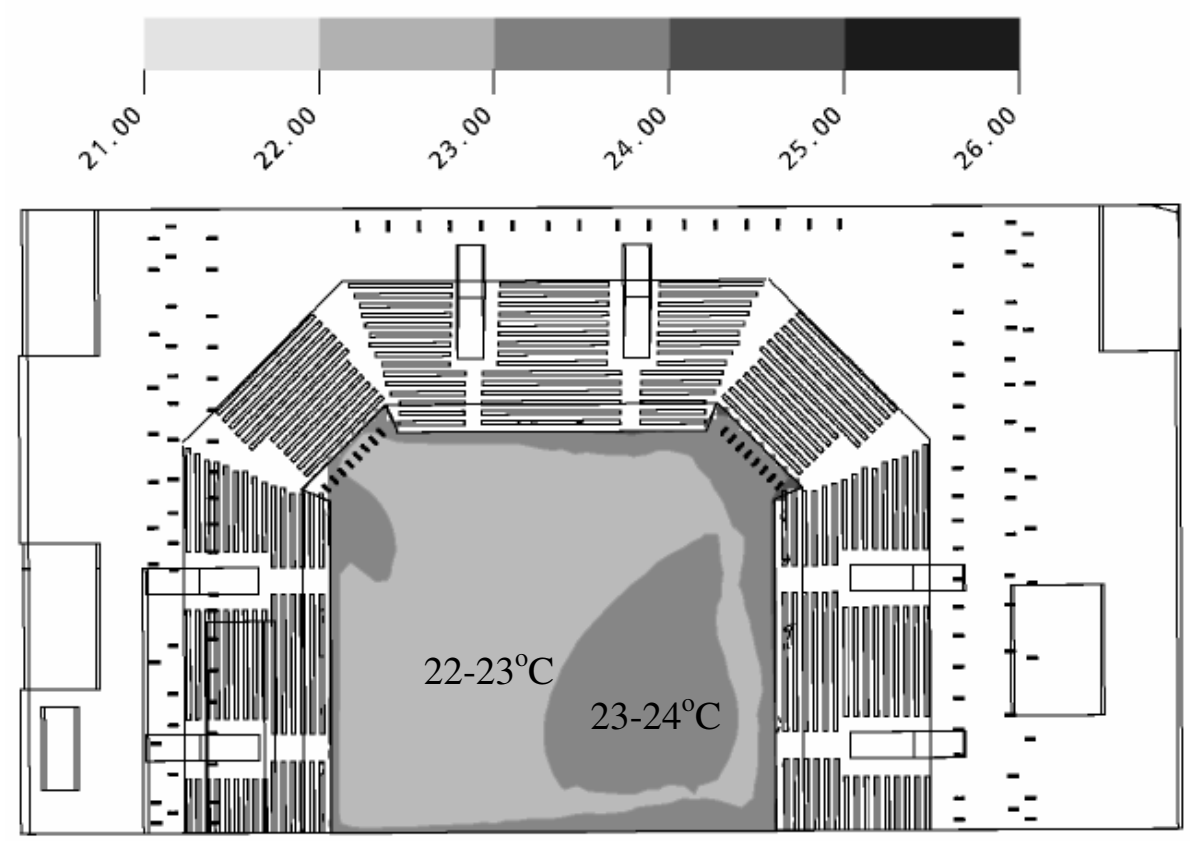

(a) $\mathrm{T}=14^{\circ} \mathrm{C}$

Temp

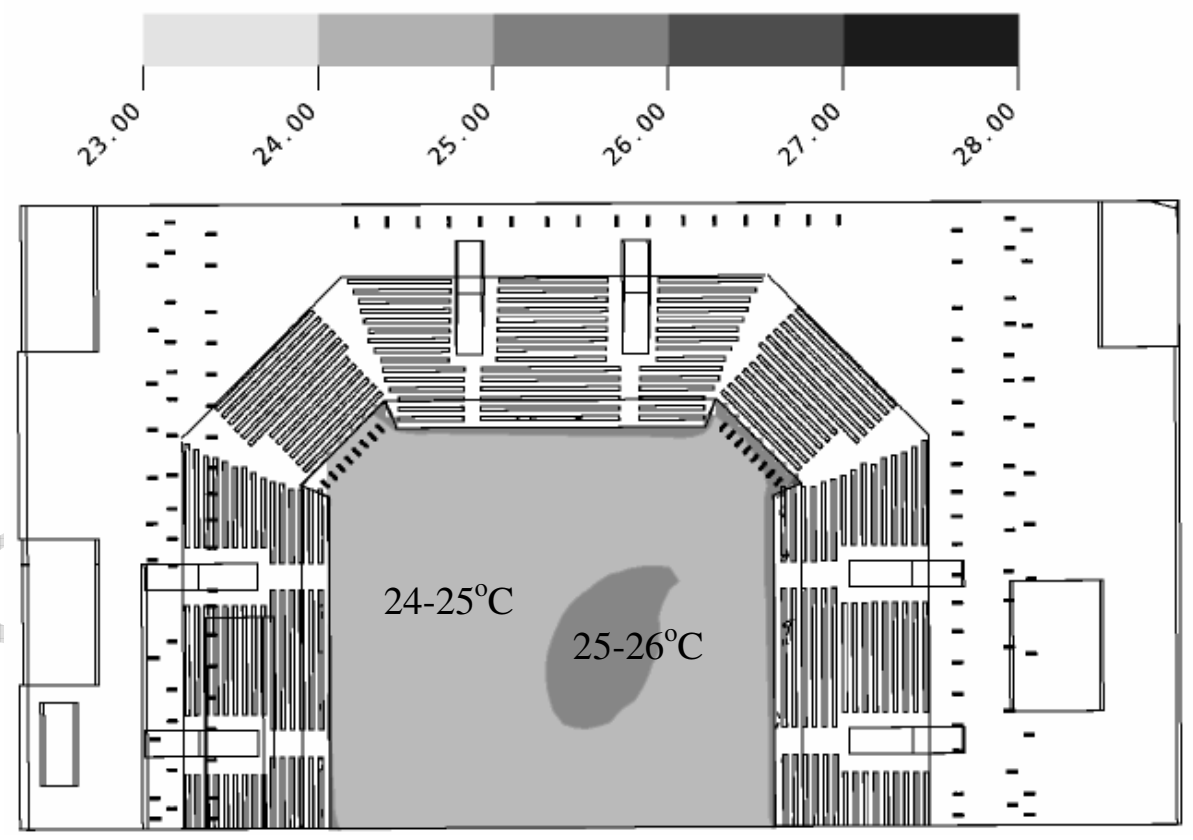

(b) $\mathrm{T}=16^{\circ} \mathrm{C}$

Figure 9 